\title{
Formulasi dan Evaluasi Secara Fisikokimia Sedian Krim Anti-Aging
}

\author{
Ira Maya*, Mutakin Mutakin \\ Program Studi Sarjana Farmasi, Fakultas Farmasi, Universitas Padjadjaran \\ Indonesia, Sumedang 45363 \\ *email: ira16001@mail.unpad.ac.id
}

\section{Abstrak :}

Penuaan secara alamiah terjadi pada makhluk hidup. Efek dari proses penuaan pada manusia adalah terjadinya gangguan secara fisik seperti kehilangan elastisitas kulit sehingga kulit menjadi keriput dan juga hiperpigmentasi. Sebagai upaya dalam mencegah maupun mengatasi hal tersebut adalah dengan menggunakan antioksidan. Antioksidan dapat menginhibisi terjadinya reaksi oksidasi sel sehingga dapat mengurangi kerusakan sel dan penuaan dini. Beberapa tumbuhan yang telah diteliti memiliki potensi sebagai antiaging adalah mahkota dewa, sirih, narwastu, rambutan, jagung, ubi jalar, kelor, raspberi, anggur dan lengkeng. Untuk memudahkan penggunaan tanaman tersebut sebagai antioksidan, bentuk sediaan kosmetik merupakan pilihan utama yang dapat digunakan secara mudah dan nyaman. Bentuk sediaan kosmetik dapat berupa sediaan gel, krim, bedak, salep dan losion. Review artikel ini akan memaparkan formulasi sediaan krim anti-aging yang mengandung zat aktif dari ekstrak tanaman. Review artikel ini menggunakan metode penelitian komparatif dengan mengumpulkan berbagi sumber pustaka primer dari 18 jurnal penelitian. Hasil review ini mengindikasikan bahwa semua krim yang diformulasikan stabil secara fisikokimia dengan tidak adanya tanda-tanda kerusakan bentuk sediaan emulsi dan perubahan sifat fisikokimia selama uji stabilitas dilaksanakan. Sehingga formula ini berpotensi digunakan dalam pengembangan formula sediaan krim yang mengandung zat aktif dari ekstrak tanaman.

Kata kunci: Anti-aging, Sediaan Krim, Ekstrak

\section{Outline}

- Pendahuluan

- Metode

- Hasil

- Pembahasan

- Kesimpulan

\section{Pendahuluan}

Indonesia merupakan salah satu negara yang memiliki berbagai jenis tanaman yang dapat digunakan sebagai bahan baku obat tradisional. Tumbuhan obat tersebut telah banyak digunakan dalam penanganan masalah kulit seperti sebagai obat jerawat, pencerah kulit dan anti-aging. 
Dalam penggunaan bahan baku obat dari bahan alam tidak cukup hanya berdasarkan pengalaman, tetapi juga perlu dibuktikan secara ilmiah. Beberapa tumbuhan yang telah diteliti memiliki potensi sebagai anti-aging adalah Mahkota Dewa (Shamsuddin, et al., 2018), Sirih (Muthukumarasamy \& Ideris, 2016), Narwastu Narwastu (Mishra, et al., 2014), Rambutan (Sekar, et al., 2017), Jagung (Safitri, et al., 2016), Ubi Jalar (Dipahayu, et al., 2014), Kelor (Sugihartini \& Nuryanti, 2017), Raspberi (Kawarkhe, et al., 2016), Anggur (Kawarkhe, et al., 2016)dan Lengkeng (Muthukumarasamy, et al., 2016).

Penuaan secara alamiah terjadi pada semua makhluk hidup, tidak terkecuali manusia. Efek dari proses ini adalah terjadinya gangguan secara fisik. Hal ini dapat terlihat gangguan secara visual proses penuaan ini adalah struktur kulit yang mengalami keriput, kehilangan elastisitas sehingga menjadi kendur dan juga terjadi hiperpigmentasi (Mulyawan \& Neti, 2013).

Proses penuaan ini dapat terjadi karena faktor intrinsik dan ekstrinsik. Faktor intrinsik yaitu penuaan yang terjadi disebabkan oleh gen, hormonal dan ras, dalam hal ini tidak dapat cegah. Sedangkan faktor ekstrinsik yaitu penuaan yang terjadi disebabkan oleh faktor eksternal seperti paparan sinar matahari, suhu, asap dari rokok, kelembaban udara serta polusi, yang dalam hal ini terjadi di luar faktor tubuh dan hal ini dapat dicegah dengan cara meminimalisir terkena faktor-faktor tersebut (Baumann, et al., 2009).

Paparan sinar matahari kronik dan repetitif disebut photoaging. Paparan tersebut menghasilkan radikal bebas yang dapat mengakibatkan kerusakan struktur maupun lapisan kulit pada lapisan dermis yaitu fibroblast dan matriks ekstraseluler seperti kolagen, elastin dan substansi dasar yang mengalami penurunan fungsi sehingga mengakibatkan kulit menjadi kehilangan elastisitas dan akhirnya menjadi keriput (Barel, et al., 2009).

Sebagai upaya dalam mencegah dan mengatasi penuaan yang diakibatkan oleh radikal bebas maka yang dapat dilakukan adalah dengan menggunakan antioksidan (Ardhie, 2011). Antioksidan ialah senyawa yang dapat memberikan satu atapun dua elektron terhadap radikal bebas, kemudian radikal bebas menjadi stabil sehingga dapat menghambat terjadinya reaksi oksidasi pada sel dan pada akhirnya mengurangi kerusakan sel yaitu penuaan (Hernani \& Raharjo, 2005).

Dalam mengoptimalkan upaya memperlambat dan mengatasi penuaan yang diakibatkan oleh radikal bebas, diperlukan suatu formulasi kosmetik yang dapat digunakan secara mudah dan nyaman. Kosmetik yang digunakan dapat berupa bentuk sediaan gel, krim, bedak, salep dan losion (Ardhie, 2011). Oleh karena itu, artikel review ini akan memaparkan tentang beberapa formulasi dan evaluasi sediaan krim anti-aging yang mengandung zat aktif dari ekstrak. 


\section{Metode}

Metode yang digunakan dalam pembuatan artikel review ini adalah metode penelitian komparatif dengan mengumpulkan berbagai sumber yang didapat dari beberapa jurnal penelitian yang berasal dari internet.

Studi literatur ini dilakukan secara online melalui jurnal-jurnal yang terdapat pada Science Direct, Researchgate, GoogleScholar, dan situs jurnal lainnya. Kriteria inklusi yaitu jurnal dan artikel yang membahas tentang formulasi sediaan krim antiaging yang mengandung bahan aktif dari ekstrak. Jumlah jurnal yang digunakan adalah 17 jurnal yang terdiri dari 9 jurnal utama dan 8 jurnal pendukung. Jurnal dan artikel yang digunakan sebagai referensi merupakan jurnal nasional dan internasional dengan kata kunci "formulation of cream antiaging" dan "formulation of cream antiaging from extract".

\section{Hasil}

Berikut ini adalah hasil telaah dari sumber data review yaitu diketahui formulasi dan hasil evaluasi secara fisikokimia sediaan krim dari berbagai ekstrak dari tabel 1 hingga 10.

Tabel 1. Komposisi Krim Antiaging dari Ekstrak Mahkota Dewa (Phaleria macrocarpa) (Shamsuddin, et al., 2018).

\begin{tabular}{|c|c|c|c|}
\hline No. & Bahan & $\begin{array}{l}\text { Jumlah } \\
(\% \mathrm{~b} / \mathrm{b})\end{array}$ & Keterangan \\
\hline 1. & Mangiferin & 1 dan 3 & Zat Aktif \\
\hline 2. & $\begin{array}{l}\text { Asam } \\
\text { stearat }\end{array}$ & 10 & Pengemulsi \\
\hline 3. & $\begin{array}{l}\text { Setil } \\
\text { alkohol }\end{array}$ & 6 & Pengental \\
\hline 4. & Parafin cair & 6.6 & Emolien \\
\hline 5. & Gliserin & 5 & Humektan \\
\hline 6. & $\begin{array}{l}\text { Metil } \\
\text { paraben }\end{array}$ & 0,05 & Pengawet \\
\hline 7. & $\begin{array}{l}\text { Propilen } \\
\text { glikol }\end{array}$ & 30 & Pengemulsi \\
\hline 8. & Air Suling & qs & Pembawa \\
\hline
\end{tabular}

Tabel 2. Komposisi Krim Antiaging dari Ekstrak Daun Sirih (Piper betel) (Muthukumarasamy \& Ideris, 2016)

\begin{tabular}{|c|c|c|c|}
\hline No. & Bahan & $\begin{array}{l}\text { Jumlah } \\
(\% \mathrm{~b} / \mathrm{b})\end{array}$ & Keterangan \\
\hline 1. & $\begin{array}{l}\text { Ekstrak } \\
\text { Daun Sirih }\end{array}$ & 2 & Zat Aktif \\
\hline 2. & Tween 80 & 2 & Pengemulsi \\
\hline 3. & $\begin{array}{l}\text { Asam } \\
\text { stearat }\end{array}$ & 6 & Pengemulsi \\
\hline 4. & Setil alkohol & 3 & Pengental \\
\hline 5. & $\begin{array}{l}\text { Propilen } \\
\text { glikol }\end{array}$ & 4 & Pengemulsi \\
\hline 6. & Gliserin & 2 & Humektan \\
\hline 7. & Mineral oil & 3 & Emolien \\
\hline 8. & $\begin{array}{l}\text { Metil } \\
\text { paraben }\end{array}$ & 0,02 & Pengawet \\
\hline 9. & Air Suling & qs & Pembawa \\
\hline
\end{tabular}

\section{Pembahasan}

Kulit merupakan organ terluar dan terluas yang berfungsi melindungi otot, ligamen, dan organ internal dari radiasi sinar ultraviolet (UV), dehidrasi, dan mikroorganisme (Fox, et al., 2011). 
Tabel 3. Komposisi Krim Antiaging dari Ekstrak Narwastu (Nardostachys jatamans) (Mishra, et al., 2014).

\begin{tabular}{|c|c|c|c|}
\hline No. & Bahan & $\begin{array}{l}\text { Jumlah } \\
(\% \mathrm{~b} / \mathrm{b})\end{array}$ & Keterangan \\
\hline 1. & $\begin{array}{l}\text { Ekstrak } \\
\text { Nawastu }\end{array}$ & 0,5 & Zat Aktif \\
\hline 2. & $\begin{array}{l}\text { Asam } \\
\text { stearat }\end{array}$ & 1,2 & Pengemulsi \\
\hline 3. & TEA & 0,165 & Pengemulsi \\
\hline 4. & Setil alkohol & 0,1 & Pengental \\
\hline 5. & $\begin{array}{l}\text { Minyak } \\
\text { Parafin }\end{array}$ & 0,3 & Emolien \\
\hline 6. & $\begin{array}{l}\text { Kondisioner } \\
\text { pelembab }\end{array}$ & 1,2 & Pelembab \\
\hline 7. & $\begin{array}{l}\text { Metil } \\
\text { paraben }\end{array}$ & 0,018 & Pengawet \\
\hline 8. & $\begin{array}{l}\text { Propil } \\
\text { paraben }\end{array}$ & 0,002 & Pengawet \\
\hline 9. & EDTA & 0,010 & Penstabil \\
\hline 10 & Air mawar & 0,4 & Pengaroma \\
\hline 11. & Air Suling & qs & Pembawa \\
\hline
\end{tabular}

Tabel 5. Komposisi Krim Antiaging dari Ekstrak Daun Kelor (Moringa oleifera) (Sugihartini \& Nuryanti, 2017)

\begin{tabular}{|c|c|c|c|}
\hline No. & Bahan & $\begin{array}{l}\text { Jumlah } \\
\text { (\%b/b) }\end{array}$ & Keterangan \\
\hline 1. & $\begin{array}{l}\text { Ekstrak Ubi } \\
\text { Jalar Ungu }\end{array}$ & 0,37 & Zat Aktif \\
\hline 2. & $\begin{array}{l}\text { Vaselin } \\
\text { Album }\end{array}$ & 6,2 & Pengemulsi \\
\hline 3. & Mineral oil & 13,8 & Emolien \\
\hline 4. & $\begin{array}{l}\text { Isopropil } \\
\text { miristat }\end{array}$ & 1,5 & Enhancer \\
\hline 5. & $\begin{array}{l}\text { Asam } \\
\text { stearat }\end{array}$ & 7,5 & Pengemulsi \\
\hline 6. & $\begin{array}{l}\text { Gliseril } \\
\text { monostearat }\end{array}$ & 5 & Penstabil \\
\hline 7. & TEA & 0,2 & Pengemulsi \\
\hline 9 & $\begin{array}{l}\text { Xanthan } \\
\text { gum }\end{array}$ & 0,2 & Pengental \\
\hline 10. & $\begin{array}{l}\text { Metil } \\
\text { paraben }\end{array}$ & 0,05 & Pengawet \\
\hline 11. & $\begin{array}{l}\text { Propil } \\
\text { paraben }\end{array}$ & 0,1 & Pengawet \\
\hline 12. & Air Suling & qs & Pembawa \\
\hline
\end{tabular}

Tabel 4. Komposisi Krim Antiaging dari Ekstrak Rambut Jagung (Zea mays) (Safitri, et al., 2016)

\begin{tabular}{|c|c|c|c|}
\hline No. & Bahan & $\begin{array}{l}\text { Jumlah } \\
(\% \mathbf{b} / \mathbf{b})\end{array}$ & Keterangan \\
\hline 1. & $\begin{array}{l}\text { Ekstrak } \\
\text { Buah Jagung }\end{array}$ & $0 \%$ & Zat Aktif \\
\hline 2. & $\begin{array}{l}\text { Propilen } \\
\text { glikol }\end{array}$ & 2,1 & Pengemulsi \\
\hline 3. & Tween 80 & 4,5 & Pengemulsi \\
\hline 4. & Span 80 & 5,5 & Pengemulsi \\
\hline 5. & Sorbitol & 20 & Humektan \\
\hline 6. & $\begin{array}{l}\text { Asam } \\
\text { stearat }\end{array}$ & 5 & Pengemulsi \\
\hline 7. & VCO & 20 & Emolien \\
\hline 8. & Asam sitrat & 0,7 & Buffer \\
\hline 9 & $\begin{array}{l}\text { Asam } \\
\text { Askorbat }\end{array}$ & 0,06 & Antioksidan \\
\hline 10. & TEA & 2,45 & Pengemulsi \\
\hline 11. & $\begin{array}{l}\text { Metil } \\
\text { paraben }\end{array}$ & 0,25 & Pengawet \\
\hline 12. & $\begin{array}{l}\text { Propil } \\
\text { paraben }\end{array}$ & 0,15 & Pengawet \\
\hline 13. & Air Suling & qs & Pembawa \\
\hline
\end{tabular}

Tabel 6. Komposisi Krim Antiaging dari Ekstrak Buah Raspberry (Rubus idaeus) dan Ekstrak Biji Anggur (Vitis vinifera) (Kawarkhe, et al., 2016).

\begin{tabular}{|c|c|c|c|}
\hline No. & Bahan & $\begin{array}{l}\text { Jumlah } \\
(\% \mathbf{b} / \mathbf{b})\end{array}$ & Keterangan \\
\hline 1. & $\begin{array}{l}\text { Ekstrak buah } \\
\text { raspberry }\end{array}$ & 2 & Zat Aktif \\
\hline 2. & $\begin{array}{l}\text { Ekstrak bij } \\
\text { anggur }\end{array}$ & 2 & Zat Aktif \\
\hline 2. & $\begin{array}{l}\text { Asam } \\
\text { stearat }\end{array}$ & 14 & Pengemulsi \\
\hline 3. & Almond oil & 0,5 & Emolien \\
\hline 4. & $\mathrm{NaOH}$ & 1 & Pengemulsi \\
\hline 5. & TEA & 0,5 & Pengemulsi \\
\hline 6. & EDTA & 5 & Penstabil \\
\hline 7. & Gliserin & 8 & Humektan \\
\hline 11. & $\begin{array}{l}\text { Metil } \\
\text { paraben }\end{array}$ & 0,1 & Pengawet \\
\hline 12 & Pengaroma & 0,5 & Pengaroma \\
\hline 13. & Air Suling & qs & Pembawa \\
\hline
\end{tabular}


Tabel 7. Komposisi Krim Antiaging dari Ekstrak Buah Lengkeng (Dimocarpus longan) (Muthukumarasamy, et al., 2016).

\begin{tabular}{|c|c|c|c|}
\hline No. & Bahan & $\begin{array}{l}\text { Jumlah } \\
(\% \mathrm{~b} / \mathrm{b})\end{array}$ & Keterangan \\
\hline 1. & $\begin{array}{l}\text { Ekstrak buah } \\
\text { lengkeng }\end{array}$ & 2,5 & Zat Aktif \\
\hline 2. & Asam stearat & 7 & Pengemulsi \\
\hline 2. & Setil alkohol & & Pengental \\
\hline 3. & Mineral oil & 0,5 & Emolien \\
\hline 4. & Gliserin & 1 & Humektan \\
\hline 5. & TEA & 0,5 & Pengemulsi \\
\hline 6. & Metil paraben & 5 & Pengawet \\
\hline 7. & Air Suling & qs & Pembawa \\
\hline
\end{tabular}

Tabel 8. Komposisi Krim Antiaging dari Ekstrak Daun Ubi Jalar Ungu (Ipomoea batatas) (Dipahayu, et al., 2014).

\begin{tabular}{|c|l|c|c|}
\hline No. & \multicolumn{1}{|c|}{ Bahan } & $\begin{array}{c}\text { Jumlah } \\
(\% \mathbf{b} / \mathbf{b})\end{array}$ & Keterangan \\
\hline 1. & $\begin{array}{l}\text { Ekstrak Daun } \\
\text { Kelor }\end{array}$ & 3 & Zat Aktif \\
\hline 2. & Asam stearat & 15 & Pengemulsi \\
\hline 3. & Setil alkohol & 6 & Pengental \\
\hline 4. & NaOH & 0,7 & Pengemulsi \\
\hline 5. & Propilen glikol & 3 & Pengemulsi \\
\hline 6. & Gliserin & 5 & Humektan \\
\hline 7. & Metil paraben & 0,3 & Pengawet \\
\hline $\mathbf{8 .}$ & Propil paraben & 0,06 & Pengawet \\
\hline 9. & Air Suling & qs & Pembawa \\
\hline
\end{tabular}

Tabel 9. Komposisi Krim Antiaging dari Ekstrak Rambutan (Nephelium lappaceum) (Sekar, et al., 2017)

\begin{tabular}{|c|c|c|c|}
\hline No. & Bahan & $\begin{array}{l}\text { Jumlah } \\
(\% \mathrm{~b} / \mathrm{b})\end{array}$ & Keterangan \\
\hline 1. & $\begin{array}{l}\text { Ekstrak Buah } \\
\text { Rambutan }\end{array}$ & $3 \%$ & Zat Aktif \\
\hline 2. & Asam stearat & 10 & Pengemulsi \\
\hline 3. & Setil alkohol & 6 & Pengental \\
\hline 4. & Parafin Cair & 6.6 & Emolien \\
\hline 5. & Gliserin & 5 & Humektan \\
\hline 6. & Metil paraben & 0,018 & Pengawet \\
\hline 7. & Propilen glikol & 0,002 & Pengemulsi \\
\hline 8. & Air Suling & qs & Pembawa \\
\hline
\end{tabular}

Tabel 10. Hasil Evaluasi Fisikokimia Krim Antiaging dari Berbagai Ekstrak

\begin{tabular}{|c|c|c|c|c|c|c|c|c|c|}
\hline Parameter & F1 & F2 & F3 & F4 & F5 & F6 & F7 & F8 & F9 \\
\hline Tipe Emulsi & $\mathrm{m} / \mathrm{a}$ & $\mathrm{m} / \mathrm{a}$ & $\mathrm{m} / \mathrm{a}$ & $\mathrm{m} / \mathrm{a}$ & $\mathrm{m} / \mathrm{a}$ & $\mathrm{m} / \mathrm{a}$ & $\mathrm{m} / \mathrm{a}$ & $\mathrm{m} / \mathrm{a}$ & $\mathrm{m} / \mathrm{a}$ \\
\hline pH & $4,8-5,6$ & 6,2 & $5,5-6,62$ & 6.5 & - & 6 & $4,30-5,20$ & $6,18-6,66$ & $4,30-5,20$ \\
\hline Penampilan & Baik & Baik & Baik & Baik & Baik & Baik & Baik & Baik & Baik \\
\hline $\begin{array}{l}\text { Homogenita } \\
\text { s }\end{array}$ & Baik & Baik & Baik & Baik & Baik & Baik & Baik & Baik & Baik \\
\hline Uji rasa & Baik & $\begin{array}{l}\text { Emolien } \\
\text { dan licin }\end{array}$ & $\begin{array}{l}\text { Emolien } \\
\text { dan licin }\end{array}$ & $\begin{array}{l}\text { Emolien } \\
\text { dan licin }\end{array}$ & $\begin{array}{l}\text { Emolien } \\
\text { dan licin }\end{array}$ & $\begin{array}{l}\text { Emolien } \\
\text { dan licin }\end{array}$ & $\begin{array}{l}\text { Emolien } \\
\text { dan licin }\end{array}$ & $\begin{array}{l}\text { Emolien } \\
\text { dan licin }\end{array}$ & $\begin{array}{l}\text { Emolien } \\
\text { dan licin }\end{array}$ \\
\hline Daya sebar & Baik & Baik & Baik & Baik & Baik & Baik & Baik & Baik & Baik \\
\hline $\begin{array}{l}\text { Uji } \\
\text { penghapusa } \\
\text { n }\end{array}$ & $\begin{array}{l}\text { Mudah } \\
\text { dihapu } \\
\text { s } \\
\text { dengan } \\
\text { air }\end{array}$ & $\begin{array}{l}\text { Mudah } \\
\text { dihapus } \\
\text { dengan } \\
\text { air }\end{array}$ & $\begin{array}{l}\text { Mudah } \\
\text { dihapus } \\
\text { dengan } \\
\text { air }\end{array}$ & $\begin{array}{l}\text { Mudah } \\
\text { dihapus } \\
\text { dengan } \\
\text { air }\end{array}$ & - & $\begin{array}{l}\text { Mudah } \\
\text { dihapus } \\
\text { dengan } \\
\text { air }\end{array}$ & $\begin{array}{l}\text { Mudah } \\
\text { dihapus } \\
\text { dengan } \\
\text { air }\end{array}$ & $\begin{array}{l}\text { Mudah } \\
\text { dihapus } \\
\text { dengan } \\
\text { air }\end{array}$ & $\begin{array}{l}\text { Mudah } \\
\text { dihapus } \\
\text { dengan } \\
\text { air }\end{array}$ \\
\hline Uji Stabilitas & $\begin{array}{l}\text { Stabil } \\
\text { selama } \\
3 \text { bulan }\end{array}$ & Stabil & Stabil & Stabil & - & - & $\begin{array}{l}\text { Stabil } \\
\text { selama } 2 \\
\text { bulan }\end{array}$ & Stabil & Stabil \\
\hline
\end{tabular}

Keterangan:

F1 = Ekstrak Mahkota Dewa (Phaleria macrocarpa)

F2 $=$ Ekstrak Daun Sirih (Piper betel)

F3 = Ekstrak Narwastu (Nardostachys jatamans)

$\mathrm{F} 4$ = Ekstrak Rambut Jagung (Zea mays)

F5 = Ekstrak Daun Kelor (Moringa oleifera)
F6 = Ekstrak Buah Raspberry (Rubus idaeus) dan Ekstrak Biji Anggur (Vitis vinifera)

F7 = Ekstrak Buah Lengkeng (Dimocarpus longan)

F8 = Ekstrak Daun Ubi Jalar Ungu (Ipomoea batatas)

F9 = Ekstrak Rambutan (Nephelium lappaceum) 
Kulit juga dapat mengalami penuaan terutama pada daerah-daerah yang sering terpapar oleh sinar matahari secara langsung seperti wajah, leher, bagian atas lengan, dan tangan. Lapisan kulit akan semakin menipis (sekitar 10\% per 10 tahun), sehingga kulit akan semakin mudah mengalami iritasi dan rapuh (Fox, et al., 2011).

Penuaan kulit terjadi karena dipengaruhi oleh radiasi ultraviolet (UV), konsumsi alkohol berlebih, penyalahgunaan tembakau dan pencemaran lingkungan. Selain itu juga terdapat faktor-faktor lain yang menyebabkan kerusakan kumulatif dalam kulit secara visual dan fungsinya yaitu genetic, hormonal, ras, suhu dan polusi (Fisher, et al., 1997; Verani, et al., 2000).

Menurut (Soyun, et al., 2009) penuaan kulit ditandai oleh pigmentasi yang tidak teratur, peningkatan kerutan, kehilangan elastisitas, kulit menjadi kering dan kasar (Bisset, et al., 1990).

Penggunaan senyawa alami dalam perlindungan kulit terutama aplikasi topikal antioksidan menunjukkan popularitasnya dalam mengurangi efek penuaan pada kulit. Antioksidan alami yang diperoleh dari tumbuhan telah dikembangkan untuk digunakan secara topikal sehingga dapat meminimalkan efek perusakan dan mencegah kondisi patologi maupun fisiologi yang terkait dengan stres oksidatif (Bernatoniene, et al., 2011).

Penggunaan antioksidan secara topikal yang dapat secara mudah diaplikasikan yaitu dibuat dalam bentuk sediaan gel, krim, bedak, salep dan losion (Ardhie, 2011). Akan tetapi pada review artikel kali ini yang akan dibahas lebih mendalam adalah sediaan krim.

Berdasarkan hasil telaah dari sumber data review tumbuhan yang telah diteliti memiliki potensi sebagai antiaging adalah mahkota dewa, sirih, narwastu, rambutan, jagung, ubi jalar, kelor, raspberi, anggur dan lengkeng. Untuk, hasil telaah dari sumber data review terkait formulasi sediaan krim dari berbagai ekstrak ini terdapat pada tabel 1-9 dan evaluasi secara fisikokimia krim antiaging yang hasilnya ditunjukkan pada tabel 10.

Secara keseluruhan dari semua krim yang diformulasikan ini termasuk pada krim emulsi jenis $\mathrm{m} / \mathrm{a}$. Krim m/a merupakan jenis krim yang memiliki fase luarnya adalah air dan fase dalamnya adalah minyak.

Keunggulan dari krim m/a ini adalah mudah dicuci dengan air, tidak lengket, tidak meninggalkan noda pada pakaian serta memiliki sifat pelepasan bahan obat yang baik dikarenakan pada saat bahan obat dioleskan pada kulit akan terjadi penguapan dan peningkatan konsentrasi obat yang larut dalam air sehingga dapat mendorong terjadinya penyerapan bahan obat menembus jaringan kulit (Aulton \& Taylor, 2013). 
Hasil dari pengukuran $\mathrm{pH}$ secara keseluruhan menunjukkan bahwa $\mathrm{pH}$ krim memenuhi syarat karena masuk pada rentang $\mathrm{pH}$ normal kulit yaitu 4,5- 6,8 (Lambers, et al., 2006) yang direkomendasikan sebagai $\mathrm{pH}$ yang sesuai dalam formulasi krim kulit kosmetik. Akan tetapi untuk nilai pH pada F5 dengan bahan aktif ekstrak daun kelor tidak diketahui sehingga untuk sediaan yang memenuhi kriteria formula yang baik.

Selanjutnya, untuk hasil uji penampilan sediaan krim yang diformulasikan tersebut memiliki penampilan yang baik dimana tidak terjadi perubahan warna saat diuji dengan metode dye sesuai dengan formula yang dibuat yaitu tetap m/a.

Selain itu, semua krim yang diformulasikan berdasarkan uji homogenitas memiliki homogenitas yang baik serta distribusi ekstrak yang homogen dalam krim yang dikonfirmasi dengan pemeriksaan visual dan sentuhan.

Kemudian, untuk hasil uji rasa semua krim yang diformulasikan memiliki rasa emolien (lembut) dan licin setelah diaplikasikan pada kulit. Rasa emolien dan licin pada kulit ini didapatkan dari eksipien yang ditambahkan pada sediaan krim yaitu zat emolien diantaranya pada $\mathrm{F} 1$ emolien yang digunakan yaitu paraffin cair, $\mathrm{F} 2$ dengan mineral oil, F3 dengan minyak paraffin, F4 dengan VCO, F5 dengan mineral oil, F6 dengan almond oil, F7 dengan mineral oil, F8 rasa emolien yang didapatkan hanya dari humektan yaitu gliserin dan propilen glikol dan F9 dengan menggunakan paraffin cair. Mekanimse emolien dapat melembutkan kulit adalah dengan cara mengisi ruang antara kulit dengan menggunakan butiran-butiran minyak.

Selanjutnya, untuk uji daya sebar ini bertujuan untuk mengetahui daya lunak dari sediaan krim yang dioleskan pada kulit. Hasil uji daya sebar dari semua krim yang diformulasikan memiliki daya sebar yang baik.

Kemudian, untuk hasil uji penghapusan didapatkan semua krim memiliki daya hapus yang baik yaitu dapat dengan mudah dicuci oleh air. Hal ini dikarenakan semua krim yang diformulasikan adalah jenis $\mathrm{krim} \mathrm{m} / \mathrm{a}$.

Semua parameter fisikokimia ini dipertahankan dengan baik selama periode studi stabilitas dipercepat diantaranya tipe emulsi, $\mathrm{pH}$, homogenitas, penampilan, uji rasa, daya sebar, uji penghapusan, serta warna sediaan.

Akan tetapi pengujian stabilitas ini tidak dilakukan pada semua formula, pengujian hanya dilakukan pada beberapa formula saja. Sehingga, berdasarkan data tersebut hanya beberapa krim yang dapat dikategorikan memiliki formula yang stabil secara fisikokimia berdasarkan hasil uji stabilitas yaitu F1, F2, F3, F7, F8 dan F9. Sedangkan untuk formula lainnya dikatakan stabil secara fisikokimia berdasarkan parameter yang telah ditentukan yaitu tipe emulsi, $\mathrm{pH}$, penampilan, homogenitas, uji rasa dan uji penghapusan. 


\section{Kesimpulan}

Hasil review ini mengindikasikan bahwa semua krim yang diformulasikan stabil secara fisikokimia dengan tidak adanya tanda-tanda kerusakan bentuk sediaan emulsi pada krim dan perubahan sifat fisikokimia selama uji stabilitas dilaksanakan. Sehingga formula ini dapat berpotensi digunakan dalam pengembangan formula sediaan krim yang mengandung zat aktif dari ekstrak tanaman.

\section{Daftar Pustaka}

Ardhie, M. A., 2011. Radikal Bebas dan Peran Antioksidan dalam Mencegah Penuaan. Scientific Journal Of Pharmaceutical Development and Medical Application, 24(1), p. 4.

Aulton, M. E. \& Taylor, K., 2013. Aulton's Pharmaceutics: The Design and Manufacture of Medicines.. Fourth ed. s.l.:Churcihill Livingstone Elsivier.

Barel, A. O., Paye, M. \& Maibach, H., 2009. Handbook of Cosmetic Science and Technology, Third Edition. New York: Informa Healthcare USA Inc.

Baumann, L., Saghari, S. \& Weisberg, E., 2009. Dermatology. New York: McGraw Hill. Bernatoniene, J. et al., 2011. Topical Apllication Of Calendula officinalis (L) : Formulation and Evaluation Of Hydrophilic With Antioxidant Activity. Journal Of Medicinal Plants Research , 5(6), pp. 868-877.

Bisset, D., Chaterjee, R. \& Hannon, D., 1990. Photoprotective Effect Of Super-Oxide Scavenging Antioxidants Against Ultraviolet Radiation-Induced Chronic Skin Damage In The Hairless Mouse. Photodermatology, Photoimmunology, and Photomedicine, Volume 7, pp. 56-62.

Dipahayu, D., Soeratri, W. \& Agil, M., 2014. Formulasi Krim Antioksidan Ekstrak Etanol Daun Ubi Jalar Ungu (Ipomoea Batatas (L.) Lamk) Sebagai Anti Aging.. Pharmaceutical Sciences and Research, 1(3).

Fisher, G. H., QW, Z. \& G, S., 1997. Pathophysiology Of Premature Skin Aging Induced by Ultraviolet Light. The New England Journal Of Medicine, Volume 337, pp. 1419-1428.

Fox, L., Gerber, M., Plessis, J. \& Hammam, J., 2011. Transderma Drug Delivery Enhancement By Compounds Of Natural Origin. Molecules, 16(10507).

Hernani \& Raharjo, M., 2005. Tanaman Berkhasiat Antioksidan. Jakarta: Penebar Swadaya.

Kawarkhe, P., Deshmane, S. \& Biyanil, K., 2016. Formulation and Evaluation of Antioxidant Face Cream Containing Raspberry Fruit and Grape Seeds Extract. Inventi Impact, 2017(4). 
Lambers, H. et al., 2006. Natural Skin Surface pH Is On Average Below 5, Which Is Beneficial For Its Resident Flora. International Journal Cosmetics Sciences, 28(5), pp. 359-370.

Mishra, A. P., Saklanil, S., Milella, L. \& Tiwar, P., 2014. Formulation and Evaluation of Herbal Antioxidant Face Cream of Nardostachys Jatamansi Colllect From Indian Himalayan Region. Asian Pacific Journal of Topical Biomedicine, 4(2).

Mulyawan, D. \& Neti, S., 2013. A-Z Tentang Kosmetik. Jakarta: PT. Elex Media Komputindo.

Muthukumarasamy, R. \& Ideris, N. A., 2016. Formulation and Evaluation Of Antioxidant Cream Containing Methanolic Extract Of Piper Betel Leaves. International Journal of Pharmaceutical and Bio Sciences, 7(4), pp. 323-328.

Muthukumarasamy, R. et al., 2016. Formulation and Evaluation of Natural Antioxidant Cream Comprising Methanolic Peel Extract of Dimocarpus Longan. International Journal of Pharmaceutical and Clinical Research, 8(9), pp. 1305-1309.

Nilforoushzadeh, M. A. et al., 2017. Dermal Fibroblast Cells: Biology and Function in Skin Regeneration. Journal of Skin and Stem Cell, 4(2).

Safitri, W. S. et al., 2016. Antioxidant Activities and Antioxidant Cream Formulation of Corn Silk (Zea Mays) Extract. Sains Medika, 7(2), pp. 64-69.

Sekar, M., Sivalinggam , P. \& Mahmad, A., 2017. Formulation and Evaluation of Novel Antiaging Cream Containing Rambutan Fruits Extract. International Journal Pharmaceutical Sciences and Research, 8(3), pp. 1056-1065.

Shamsuddin, A. M., Sekar, M. \& Musa, A. Z., 2018. Formulation and Evaluation of Antiaging Cream Containing Mangiferin. International Research Journal of Pharmacy, $9(6)$.

Soyun, C. et al., 2009. Dietary Aloe Vera Supplementation Improves Facial Wrinkles and Elasticity and It Increases The Type I Procollagen Gene Expression In Human Skin In Vivo.. Annals Of Dermatology, Volume 21, pp. 6-12.

Sugihartini, N. \& Nuryanti, E., 2017. Formulasi Krim Ekstrak Daun Kelor (Moringa oleifera) Sebagai Sediaan Antiaging. Berkala IImu Kesehatan dan Kelamin-Periodical of Dermatology and Venerology., 29(1).

Verani, J. et al., 2000. Vitamin A Antagonizes Decreased Cell Growth and Elevated Collagen-Degrading Matrix Metalloproteinases and Stimulates Collagen Accumulation in Naturally Aged Human Skin. Journal Of Investigative Dermatology, Volume 114, pp. 480-486. 